\title{
ENVIRONMENTAL ACTIVISM DURING COMMUNIST ERA IN SLOVENIA
}

\author{
Željko OSET*
}

Upon 1945, the Yugoslavian communist leadership put in motion ambitious strategy of industrialization and modernization regardless of costs, hence gradually evolving issues of environmental degradation were placed in a subservient position. Some planners deemed environmental degradation a necessary evil in order to fulfill pledges of development, progress, and better living standard. However, from the 1970s onwards environmental issues were addressed in urban planning, improvement of central-heating systems, by setting out emission thresholds, and mandatory environment clearance for credits approval for corporative entities, but law enforcement was not upheld to the highest standards and in full.

The League of Communists of Slovenia allowed rather loosely knitted grass-roots environmental enthusiasts since the late 1960s; groups were comprised with well-educated citizens, which were mostly keen mountaineers. Environmentalists were especially active in urban areas mostly dealing with local issues (urban planning, sewage systems, contamination of the tap water, and excessive use of pesticides and fertilizers).

In 1971, local environmental societies merged into the Association for Environmental Protection in Slovenia (AEPS), which in the late 1970s focused broadened scope of activities, mainly against the construction of hydroelectric power installations on the Soča River and the Mura River, and the Nuclear Power Plant Krško after the Chernobyl accident. In the 1970s, in Yugoslavia and Slovenia as well, concurrently with the West, modern legislation for environmental protection was adopted, and new self-government bodies for environmental issues comprising with politicians, lawyers, scientists, and environmentalists were established; thus the influence of AEPS somehow diminished.

* Željko Oset, Ph. D., University of Nova Gorica, Nova Gorica, Slovenia 
The Slovenian government increased finances for research, and at the same time in the environmental debates replaced politicians with technocrats, who proved to be unwilling listeners to environmentalists' complaints and suggestions. The environmentalists were accused by a top-level politician of being exaggerators, followers of Western initiatives and in general obstructers of development.

In 1980s environmentalists broadened its ranks and scope of activities, especially after the Chernobyl Nuclear Accident. Environmental societies and society were attracting people who were interested in changes but did not want to risk direct political opposition and the consequences of this type of direct dissent. Slovenian environmental groups played an important role during the democratization. In 1989 they even established a political party 'Zeleni Slovenije' (Greens of Slovenia). The party was a partner in the first post-communist Slovenian government (1990-1992), and they successfully pushed for incorporation of 'green policies' in the Slovenian legislation.

Keywords: 1970s, 1980s, Yugoslavia, Slovenia, Environmental activism, Association for Environmental Protection in Slovenia (AEPS), Greens of Slovenia

\section{Marshall Plan for the ecological rehabilitation?}

In September 1990, in Berlin, UNESCO organized conference Science and Technology for the Future of Europe, where an issue of environmental degradation was high on the agenda. It was a time of groundbreaking political and economic changes with the demise of planned national economies, and the process of disintegration of regional alliances and even countries, therefore it was de facto a scholar debate about future of Europe. Robert Blinc, vice-president of the Slovenian Academy of Sciences and Arts and representative of the Council of Yugoslavian Academies of Sciences and Arts, argued that division in Europe is more pronounced than ever, however not in the traditional political dichotomy West and East, but rather into the rich and the poor, countries with established environmental governance and the other ones. Thus Blinc proposed a Marshall Plan for the ecological rehabilitation of Eastern Europe's industry with the help of the international community. Blinc argued the West owed financial support to ex-communist countries for an absence of support after the World War II to independently choose their modes of governance. ${ }^{1}$

\footnotetext{
The Yearbook of the Slovenian Academy of Sciences and Arts: book 41, 1990 [Letopis Slovenske akademije znanosti in umetnosti, 41. knjiga, 1990] (Ljubljana: Slovenska akademija znanosti in umetnosti, 1991), p. 155.
} 
Although the European Union and some member states provided limited amounts of technical and financial support, mainly through the PHARE Programme, and additionally through the European Investment Bank and newly established the European Bank for Reconstruction and Development. This was only dribs and drabs, way short of expectations or needs, incomparable with Marshall Plan for Western Europe after the World War $\mathrm{II},{ }^{2}$ yet it gave relevance to environmental issues in post-socialist countries. ${ }^{3}$

The market-oriented reforms in transition in Slovenia put domestic already stained industry under additional pressure; thus struggling firms had to decrease their production or even closed factories altogether. Hence reforms had enormous economic, social and cultural cost. The transition of Slovenian economy was a groundbreaking test for the Slovenian government comprised with the Greens of Slovenia. ${ }^{4}$

\section{Development!}

History of Europe after World War II is entangled into the dichotomy WestEast, however sticking point is rebuilding of the national economies and societies, and laying foundations for "permanent" economic growth as well. Economic growth in the West was facilitated by growth-minded governments, although without people support and pay-restraint of workers all national "wirtschaftswunders" would not be possible or at least would happen in different extent and timescale. And in early 1970's, for the Western Europe, this golden age as it was dubbed, defined by high growth of GDP and full employment, ended due to various reasons, to name for our discussion the most important, new assertiveness of the populace and evaporated readiness to sacrifice in the interest of postwar reconstruction. ${ }^{5}$

In the East, Yugoslavia included, the postwar industrialization was based on the Soviet Union experience with industrialization and modernization of society at large, and fear of another war as well, thus self-sufficiency was promoted. A promise of development and the role of communist in the resistan-

\footnotetext{
$2 \quad$ Barry Eichengreen, The European economy since 1945: coordinated capitalism and beyond (Princeton, N.J.: Princeton University Press, 2007), pp. 306-308.

3 Balázs Trencsényi, Michal Kopeček, Luka Lisjak Gabrijelčič, Maria Falina, Mónika Baár, and Maciej Janowski, A History of Modern Political Thought in East Central Europe: Volume II: Negotiating Modernity in the "Short Twentieth Century" and Beyond: part II: 1968-2018 [Oxford: Oxford University Press, 2018], pp. 309-310.

4 Aleksander Lorenčič, Prelom starim in začetek novega: tranzicija slovenskega gospodarstva iz socializma $v$ kapitalizem, 1990-2004 [Break with the old regime and the new beginning: the transition of the Slovenian economy from socialism to capitalism, 1990-2004] (Ljubljana: Inštitut za novejšo zgodovino, 2012).

5 Barry Eichengreen, The European economy since 1945, pp. 100-219.
} 
ce lent their argument a veneer of legitimacy, thus selection of concept of development. Yugoslavia, even after the Cominform, or especially after the breakup with the Eastern Bloc, has strengthened ethos of self-sufficiency, proceeded with extensive development based on the heavy industry despite lacking raw materials, expertise, and capital, thus leadership took rigorous measures of capital formation in order to achieve economic and political-ideological goals as well. ${ }^{6}$

For economic planners growth was imperative regardless of costs since new factories were a sign of progress, opportunity for employment and higher living standard. ${ }^{7}$ Yet due to noticeable environmental degradation those issue had to be addressed. The Slovenian government supported research on treatment of industrial wastewater, ${ }^{8}$ which followed by more research although in a limited scope and extent till the early 1970s, when the Slovenian research community, a semi-autonomous body responsible for the financing of science and research in industry, allocated more funds. ${ }^{9}$ Even more, foreign researchers were awarded grants to research in Slovenia, ${ }^{10}$ and Slovenian ones were supported to do postdocs abroad. Yugoslavia also received American technology in limited extent and accepted foreign investment, especially in the car industry (Zastava, Revoz). It also invested in development of domestic techno$\operatorname{logy}{ }^{11}$ however industrial plants polluted the environment to an extent that would have been unthinkable in the West, where leaders were democratically accountable. Altogether, openness to the West brought astounding challenge to "utopian project" of communism with human face, and especially to promise of better life. ${ }^{12}$

\footnotetext{
$6 \quad$ Ibid.; Jože Prinčič, Pot do slovenske narodnogospodarske suverenosti 1945-1991 [The way to Slovenian national economic sovereignty 1945-1991] (Ljubljana: Inštitut za novejšo zgodovino, 2013).

7 Zdenko Vrdlovec, Mako Sajko ali "odkritje neznanke" [Mako Sajko or "discovery of enigma"] Dnevnik (https://www.dnevnik.si/1042305816), September 1, 2017; See also: Benjamin Tromly, Making the Soviet intelligentsia: universities and intellectual life under Stalin and Krushchev. (Cambridge: Cambridge University Press, 2015), pp. 20-25.

8 Željko Oset, "Kemični inštitut Borisa Kidriča v letih med 1946 in 1959." "Chemical Institute Boris Kidrič between 1946 and 1959”] In: Branko Stanovnik et al. eds., Maks Samec 1881-1964, življenje in delo, zbornik ob 50-letnici smrti [Maks Samec 1881-1964, life and work, monograph on the occasion of his 50th anniversary of the death] (Ljubljana: Slovensko kemijsko društvo, Slovenska akademija znanosti in umetnosti, 2015), p. 190.

9 Javna agencija za raziskovalno dejavnost Republike Slovenije [Slovenian Research Agency], (https://www.arrs.si/sl/finan/letpor/), January 15, 2017.

10 David E. Kromm, "Perception of the air pollution hazard in Ljubljana, Yugoslavia" In: Ivan Volgyes ed., Enviromental Deterioration in the Soviet Union and Eastern Europe (New York, Washington, London: Praeger Publishers, 1972), pp. 138-140.

11 Archives of the Republic Slovenia, AS 223, b. 321, Zapisnik 31. seje IS LRS (June 8, 1959).

12 Viktor Blažič, "Slovenske ekološke katastrofe" ["Slovenian ecological disasters"], Nova revija [New Magazine] (1990), no. 93-94: 218-221.
} 
In the 1960s, the Slovenian government, more vaguely already under Boris Kraigher and then with more systematically under Stane Kavčič purposed transformation of Slovenian economy towards services and durable goods, thus labor and energy less intensive industries, though quite opposite happened. ${ }^{13}$ With massive capital investment old concept survived for additional 1520 years. ${ }^{14}$ A significant shift happened occurred in 1987, when Slovenian authorities decided rather than to building additional electrical capacity, the cornerstone of all previous plan documents, as was planers in Belgrade for Yugoslavia demanded, to boost investments in more efficient use of energy. ${ }^{15}$

\section{Association for Environment Protection in Slovenia and its beginnings}

Important milestone for Slovenian environmental activism was the establishment of the Association for Environment Protection in Slovenia, in 1971. It was an unprecedented and controversial decision of Slovenian government at that time. Civil organization under communism were limited, thus approval of AEPS rules by the government enraged some hard-line communists, who argued that there is no real need to open public debate about environmental degradation and by that offer possibility to empower few keen local environmentalists that already protested against building hydro power installations in the protected Triglav National Park. Moreover, give them the opportunity to take credit for governments remedying measures - for example, the central heating system in cities, sewage treatment plants -, thus encouraging more demands and straining public funds even further. Even though the Slovenian government did not support AEPS in full and unconditionally, it sought some kind of an alliance with activists or as a tool for aligning the environmental discourse with government plans, e.g. in the struggle with Belgrade for funds and investments in Slovenia. ${ }^{16}$

Namely, in first two decades after the World War II, due to enormous economic disparities between the industrialized north and the agrarian south, the majority of state investments were made in underdeveloped regions, which generated frustrations among the more developed republics; especially Slovenia, which was the most developed of them. Slovenian communist demanded more

13 Božo Repe, Jože Prinčič, Pred časom, portret Staneta Kavčiča [Before time: a biography of Stane Kavčič] (Ljubljana: Modrijan, 2009), pp. 75-97.

14 Ibid.

15 Jože Prinčič, "Strategije energetske stabilnosti ter pridobivanje in poraba premoga v letih 1945-1991" ["Energy Stability Strategy and Coal Production and Consumption in the period 1945-1991”] In: Aleksander Lorenčič, Žarko Lazarević (eds.), Strategije in prakse energetske oskrbe $v$ Sloveniji [Strategies and practices of energy supply in Slovenia] (Ljubljana: Inštitut za novejšo zgodovino, 2015), pp. 263-265

16 Zbirka okoljskega gradiva Alenke Bizjak [Alenka Bizjak Environmental Collection]. 
funds for modernizing old factories, and thus the ability to raise living standard in Slovenia because this was one of the fundamental sources of their legitimacy the promise to improve the living standard and enable consumerism. They were under pressure since the borders with neighboring Austria and especially Italy were open due to bilateral agreements between Yugoslavia and the respective neighboring countries. Therefore people could not only buy in Slovenia inaccessible goods but also compare the standard of living in those countries. Due to the weak result of investments frustrations among Slovenian leadership was growing, but their political struggle was limited to internal debates and lobbying. ${ }^{17}$

The Slovenian government tried to acquire popular support in the struggle with Belgrade for additional funds and investments. However, why is that important for the environmental history? Using outdated technology and machinery, some of them 90 years old, had a negative impact. From the government point of view, the principal issue was the production level and reliability of the working process. The Slovenian government tried an unorthodox approach, in 1964 they financially supported, through Slovenian movie fund, a short movie with the telling title Strupi - Poisons was filmed. ${ }^{18}$ And three years later the Slovenian movie fund supported another short movie about state of affairs in Slovenian industry - the movie was titled Muzej zahteva - Museum calls; the short movie conveyed the massage that Slovenian factories resemble museums. ${ }^{19}$

The short movie Strupi - Poisons depicts environmental degradation as direct and undisputed result of a steel factory in a small basin. There are several takes from the movie. One of them is that we have involuntarily trade-off between industry and farmers, who lost their income as a result of pollution. Director Mako Sajko was aware of standing on a slippery slope; hence the movie is without commentary, which was already an established practice when showing a controversial issue on the national television. Nonetheless, by using Manichean contrast of scenes between unspoiled nature and dying world, finger pointing, and music as well, the story about the impact of industry on the environment is told. ${ }^{20}$

Director Mako Sajko upon the filming of the movie has consulted with a director of a steel factory and asked him if there are any restrictions for filming crew. For example, if it is allowed to film chimney while emitting smoke. The

\footnotetext{
17 Jože Prinčič, “Gospodarska reforma” [Economy reform] In: Jasna Fischer et al. (eds.), Slovenska novejšo zgodovina: od programa Zedinjena Slovenija do mednarodnega priznanja Republike Slovenije: 1848-1992. [Slovenian Contemporary History: from the Programe United Slovenia till international recognition of the Republic Slovenia: 1848-1992] (Ljubljana: Mladinska knjiga, 2005), pp. 1045-1049.

18 Slovenian Film Centre, Mako Sajko (https://www.film-center.si/sl/film-v-sloveniji/fil$\underline{\mathrm{mi} / 2355 / \text { strupi/), September 1, } 2017 .}$

19 Slovenian Film Centre, Mako Sajko (https://www.film-center.si/sl/film-v-sloveniji/fil-

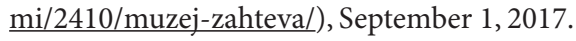

20 Youtube, Strupi - First European Ecological Movie - Mako Sajko (https://www.youtube. com/watch?v=BtGTbjZH2rM), September 5, 2017.
} 
director replied with a smile on his face: "Guys, this is black smoke, but for you red color would be more interesting, right?" Additionally, the director voluntarily showed filming crew sewers that emitted pollutants to a river. Sajko asked him: "How come you are so happy to tell us this dirt is coming from your factory?" and, he enthusiastically replied: "Yes, this is a sign that we are working good. Look at the factory on the hill. There is no smoke and no sewage. Why? Because they are out of business, and workers were laid off!"21

\section{Intellectual background of AEPS's members and UN conference}

Rachel Carson's book Silent spring educated the public regarding the hazards of the indiscriminate use of pesticides, many of which the effects were not fully known. Silent Spring not only raised awareness about the issues of pesticides but also taught us about the ecological systems of which we all are a part, encouraging society to reexamine people relationship to the natural world, including in Slovenia. ${ }^{22}$

In this sense, we could discuss about organized grass-roots activism, which originated in groups of people, who were inspired by the mesmerizing beauty of Slovenian Alps, or was members of scholarly societies, thus they were drawn out of degradated environment into woods or mountains. ${ }^{23}$ One of them, France Avčin, who is regarded as an instigator of environmental activism in Slovenia, in the late 1960s, wrote three influential books: Whispers of silence (Kjer tišina šepeta), Life of mountaineer (Iz življenja gornika), Human being against nature (Človek proti naravi). ${ }^{24}$ Avčin's books were source of inspiration for the monograph The Green Book on the threat to the environment in Slovenia (Zelena knjiga o ogroženosti okolja v Sloveniji), a collaborative effort of Slovenian scholars published in 1972 by the Slovenian Natural Society. It was one of preparation activities for the United Nations' Conference on Human Environment in 1972 in Stockholm. ${ }^{25}$

\footnotetext{
$\overline{21}$ Zdenko Vrdlovec, "Mako Sajko or 'discovery of enigma”, September 1, 2017.

22 William Cronon, Silent spring and the birth of modern environmentalism. Thomas Dunlap, DDT, Silent Spring, and the Rise of Environmentalism, classic text (Seattle: University of Washington Press, 2008), pp. IX-XI.

23 France Avčin, Kjer tišina šepeta [Whispers of silence] (Ljubljana: Mladinska knjiga, 1964), pp. 7-9.

24 Avguštin Lah, "Slovenija, varstvo in urejanje okolja" ["Slovenia protection and regulation of the environment"] In: Avguštin Lah (ed.), Slovenija 88, okolje in razvoj, zbornik [Slovenia 88, Environment and Development, Proceedings]. (Ljubljana: Slovenska akademija znanosti in umetnosti, 1989), pp. 21-24.

25 Stane Petrlin et al. (ed.), Zelena knjiga o ogroženosti okolja v Sloveniji [The Green Book on the threat to the environment in Slovenia] (Ljubljana, Prirodoslovno društvo Slovenije, 1972). See also: Barbara Ward, René Dubos, Only One Earth: The Care and Maintenance of a Small Planet (Harmondsworth: Penguin Boook Lts., 1972).
} 
Relatively concurrently with the other Western European countries, Yugoslavia adopted legislation on environment protection, and proclaimed right to live in a clean environment as basic human right. Although the socialist economic model theoretically included the costs of pollution in the cost of products in comparison with the external treatment inherent in the market economy, the main issue was the lax law enforcement and the lacking social guidance about pollution hazards. ${ }^{26}$ Authorities had kept a close eye when the economic interest was at stake. In Yugoslavia was strong preproduction bias and investment location which resulted in a continued neglect of infrastructure, a reluctance to divert funds to pollution control, and impotency and ineffectiveness in the enforcement of regulations. ${ }^{27}$ On the other hand, the ecological discourse was under scrutiny, so environmental issues in Slovenia were sometimes relativized, by presenting or even extrapolating environmental issues in capitalist countries. And the massage was: environmental issues are inherent to capitalism unlike socialism where are only an issue in the early stages of development into communism. To some extent development of homegrown ecosocialists thought was supported. ${ }^{28}$

\section{Environmentalists versus technocrats}

In the 1970s, in Yugoslavia and Slovenia as well, modern environmental legislation was passed, new self-government bodies for environmental issues comprising with politicians, lawyers, scientists, and environmentalists were established; thus the impact of AEPS diminished. The Slovenian government also increased funds for research, and empowered professionals with technical background to lead debates with environmentalists. Technocrats, as they were called, proved to be in most cases unwilling listeners to environmentalists' complaints and suggestions. ${ }^{29}$

Environmentalist and scholars shared information about environmental hazards and endangerment of flora and fauna, however on top of their agenda was their opposition to construction of hydropower installations in the pristi-

\footnotetext{
26 Victor L. Mote, “Air pollution in the USSR” In: Ivan Volgyes, ed., Environmental Deterioration in the Soviet Union and Eastern Europe (New York, Washington, London: Praeger Publishers, 1972), p. 37; David E. Kromm, "Perception of the air pollution hazard in Ljubljana, Yugoslavia" In: Ivan Volgyes, ed., Enviromental Deterioration in the Soviet Union and Eastern Europe (New York, Washington, London: Praeger Publishers, 1972), pp. 138-140.

27 Viktor Blažič, "Slovenske ekološke katastrofe" ["Slovenian ecological disasters”], Nova revija [New Magazine], (1990), no. 93-94: 218-220.

28 Dušan Plut, "Odnos do človekovega okolja v luči družbeno-ekonomskih sistemov" ["Relation towards the human environment in the context of socio-economic systems"], Geografski obzornik: časopis za geografsko vzgojo in izobraževanje [Geographical horizon : newspaper for geographical teaching and education], 1975, no. 3-4: 6-10.

29 Zbirka okoljskega gradiva Alenke Bizjak [Alenka Bizjak Environmental Collection].
} 
ne environment, for example in the Triglav National Park. Legal protection did not stop proponents for generating new watts, who for almost 20 years tried to start building the dams in Upper Soča Valley. ${ }^{30}$ Their main argument was meeting demand of electricity, which increased more than 40 fold till 1992 in comparison to pre-WW II level in Slovenia. ${ }^{31}$ Building new plants was in line with country policy until 1987, when Slovenian leadership decided to concentrate on more efficient use of energy. Some projects had been delayed in 1986 till year 2000, and then canceled. ${ }^{32}$

The decision-making process to build new hydropower plants was complex, and unpredictable to say at least. Such example was a plan to building a hydropower plant in Bohinjska Bistrica near Bled in the late 1950s. Technical elaborates were made, but then the president Josip Broz, who occasionally hosted foreign dignitaries or enjoyed summer break in "his" Bled villa, stated opposition against the project. After his death proponents tried one more time, but this time project was turned down on the local referendum. One could argue that is a textbook not-in-my-backyard complex and sign of environmental awareness, which was emerging within group of well to do individuals, who in capitalist countries were moving to suburbs, and in Slovenia, they sought refuge at their weekend-cottages. ${ }^{33}$

Proponents, Emil Pintar dubbed them energy lobby, of new power installations insisted that all home natural sources should be used for generating electricity, including rivers and lakes in natural parks. Slovenian authorities allowed limited public discussion, which was an opportunity for locals and moreover for the grass-roots activist to publically oppose to building new dams on pristine mesmerizing rivers or on polluted rivers. ${ }^{34}$ The level of dialogue between proponents and the interested public clearly illustrates the "incident" at the symposium in November 1965, during which they discussed the possibility of building new facilities in the Upper Soča Valley. When an opponent of the construction of a hydropower plant in the Upper Soča Valley presented his case, and argued vehemently against the dam, someone turned off the lights. ${ }^{35}$

In the 1970s and 1980s, the most contentious issues for environmentalist were plans to harness energy on the Soča River, the Cerknica Lake, and the

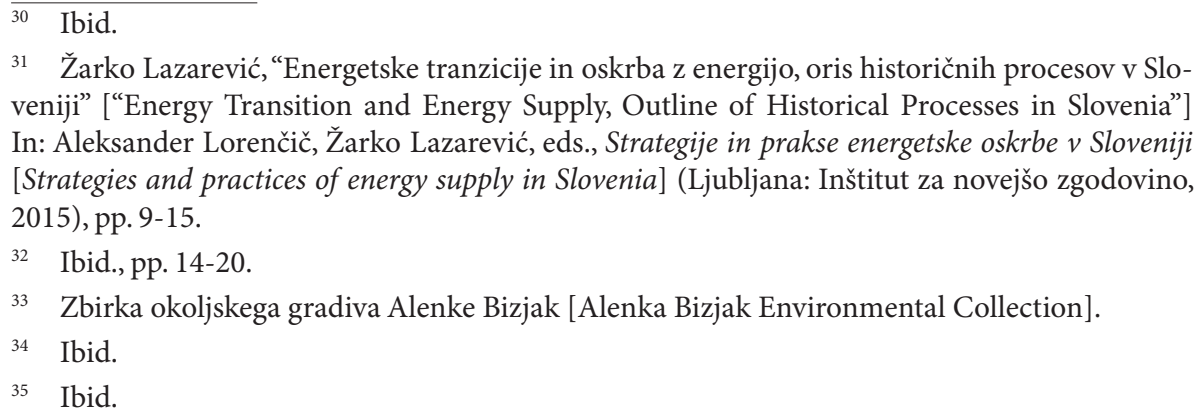
veniji" ["Energy Transition and Energy Supply, Outline of Historical Processes in Slovenia"] In: Aleksander Lorenčič, Žarko Lazarević, eds., Strategije in prakse energetske oskrbe v Sloveniji [Strategies and practices of energy supply in Slovenia] (Ljubljana: Inštitut za novejšo zgodovino, 2015), pp. 9-15.

32 Ibid., pp. 14-20.

33 Zbirka okoljskega gradiva Alenke Bizjak [Alenka Bizjak Environmental Collection].

34 Ibid.

35 Ibid. 
Mura River. The struggle for the intact Upper Soča Valley for environmentalist was a formative experience since environmentalist were debating with technical experts, professionals, unlike activist who were amateurs. Activists developed techniques and competence, and wide net of informers as well. ${ }^{36}$ AEPS established its own communication network, however, publications in the newspapers were warranted. Although the chances for publications of public letters were slim, environmentalists were persistently sending their articles to the editors and their colleagues, but also to proponents of new electricity installations, with an aim to force broad public discussion and to be a stakeholder in the decision-making process. Also due to their persistent efforts Slovenian parliament in 1980 suspended projects to build dams in the Upper Soča Valley, in 1985 suspended project on the Cerkinca Lake - the plan stipulated sealing karsts sinkholes with concrete in order to build a multifunctional lake, and in 1986 citizens on local referendum declined project to build a dam on Sava Bohinjka near Radovljica. ${ }^{37}$

The last major "battleground", between environmentalist and proponents who in mid-1980s lost the support of Slovenian politics, was the Mura River. As mentioned, new long-term agenda for 1986-2000 period was based on assumptions of efficient use of energy rather building new capacity, ${ }^{38}$ and new dams were expensive and unpopular, and for Mura River, multilateral agreement with Austria and Croatia would have to reach, thus the government decided to postpone project to end of long-term agenda in the year 2000. The success put environmentalists, who opposed the project under slogan Save with energy-Preserve Mura (Varčujmo z energijo-Rešimo Muro), at the heart of impending interest for the environment which was overlapping with global debate on sustainability and global warming. ${ }^{39}$

\section{Milestones for AEPS in 1980s}

In 1984, among Slovenian environmentalists and public alike resonated contamination of the Krupa River with poisonous chemical PCB. The chemical was seeping from industrial reservoirs to the underground. Although findings, discovered "unintentionally" during feasibility study to build new water supply to the region Bela krajina, were alarming Slovenian authorities reacted slowly and with discerning tones towards alarming information of activist who tried to inform Slovenian and Croatian public about the natural di-

\footnotetext{
36 Avguštin Lah, Slovenija sedemdesetih let [Slovenia in 1970's] (Ljubljana: Državna založba Slovenije, 1977), p. 340.

37 Zbirka okoljskega gradiva Alenke Bizjak [Alenka Bizjak Environmental Collection].

38 Žarko Lazarević, "Energetske tranzicije in oskrba $\mathrm{z}$ energijo, oris historičnih procesov v Sloveniji”: 9-15.

39 Zbirka okoljskega gradiva Alenke Bizjak [Alenka Bizjak Environmental Collection].
} 
saster with a hint about possible industrial pollutions spots in their backyard. Information was put under embargo, and the morning newspaper Delo published only a few short articles with substantial time delay, though public letters were turned down. However, the extent of contamination was enormous that the news eventually resonated in Slovenian public opinion thus energized grass-root environmental movement and process of democratization in Slovenia as well. ${ }^{40}$

Iskra kondenzatorji was "successful" action of local activists who with the support of the AEPS, as an issue that facilitated the awareness how human activities affect the environment and what people can do to stop environmental destruction. Because people do not usually take action to correct a problem until they see how it relates to them. ${ }^{41}$

Breakthrough of environmentalists into mainstream happened upon the Chernobyl Nuclear Accident on 26 April 1986. Prior to the Chernobyl disaster, mostly favorable information about nuclear energy were circulated; critique was limited to an ideological dimension, namely the neo-colonial export of know-how and an unfavorable (overpriced) capitalist financial arrangement between the West and nonaligned Yugoslavia. Everything changed after the Chernobyl disaster. Following an uneasy situation, an increasing number of opportunities for public debate about nuclear energy arose in socialist Slovenia. Grass-root environmentalists, who were actively campaigning against the building of new hydropower plants in pristine environments, were energized. ${ }^{42}$ They drew attention to the state's negligence in relation to discharges of toxic industrial waste in the natural environment, something which had been ongoing since the early 1970s; people were prepared to listen and joined ranks with environmentalists. ${ }^{43}$

\section{Democratization and Green party in Slovenia}

Environmentalists participated in the process of democratization in the late 1980s in Slovenia. After the Chernobyl accident, they established a wider platform to address the public, and become an important part of civil society that created one of semi-legal channels for political and social activism. Environmental societies were attracting people who were interested in changes but did not want to risk direct political opposition and the consequences of this

\footnotetext{
40 Dušan Plut, Slovenija - zelena dežela ali pustinja? [Slovenia - a green country or a desert?] (Ljubljana: Krtina, 1987).

${ }^{41}$ Zbirka okoljskega gradiva Alenke Bizjak [Alenka Bizjak Environmental Collection]. See also: Andrej Klemenc, Hubert Požarnik et al. Ekološko gibanje, politika, morala [Ecological movement, politics, and morale] (Ljubljana: Časopis za kritiko znanosti, 1992).

42 Zbirka okoljskega gradiva Alenke Bizjak [Alenka Bizjak Environmental Collection].

43 Interview with Alenka Bizjak (January 20, 2016).
} 
type of direct dissent. They participated in decision-making process about the groundbreaking substantive solutions on the planned restructuring of the economy and also in the process of democratization. A rather small but well organized group of members inside AEPS put behind conservations agenda in correlation with evolving democratization in Slovenia, and they were critical towards consumerism. However, majority members of AEPS were still pursuing basic conservationist's strategy - they supported consensual social goals within the existing socio-economic structure, and simultaneously brought attention to an unrecognized issue that society already supported, therefore they retained their main operational goal - to be heard in be an integral part of decision-making process. ${ }^{44}$

With the democratic changes, the re-introduction of free and multiparty elections on the national level in 1990, the environmentalists organized their own party - The Green Party. With a broad green agenda, including the closure of the Žirovski Vrh uranium mine and the Krško nuclear power plant, Slovenia's grassroots environmentalists received substantial support $(8,8 \%)$ in the parliament elections in April 1990. ${ }^{45}$ The party Greens of Slovenia became part of the coalition government; however, their political promise to phase out the Krško Nuclear Power Plant was quietly abandoned in light of political and economic issues that were perceived as crucial. Namely, if Slovenia was to achieve independence, it would need economic stability and its own independent power generation and distribution system, thus the Krško Nuclear Power Plant was essential to this aim. The Green's attitude towards the Krško Nuclear Power Plant henceforth followed the general line of public opinion. ${ }^{46}$

Although the Greens of Slovenia were soon eliminated from the parliament, on one hand due to party infighting and greening of Slovenian politics on other hand, they left an important legacy: they put environmental issues in the mainstream and influenced public discourse as well, influenced long-term legislation, raised the environmental awareness, last but not least they are greened Slovenian politics. Their experiences show that political success can have an adverse effect, on a green party and also on social placement of environmental issues. ${ }^{47}$

In the excellent study for Hungary, Marni Berg emphasize irony, that environment groups in Hungary have less influence in democracy than they had

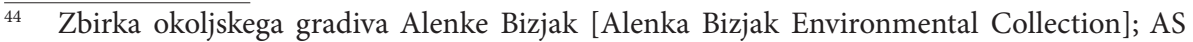
2017, box 1 .

45 Statistični letopis Republike Slovenije, 1992. [Statistical Yearbok of the Republic of Slovenia, 1992] (Ljubljana: Statistični urad Republike Slovenije, 1992), pp. 93-95.

46 AS 2017, box 2.

47 Ibid.

48 Marni Berg, "Red and Gren, Twenty Years of Environmental Activism in Hungary", Problems of Post-Communism, vol. 47 (2000), no. 2: 46-56.
} 
in the period of communism, which is similar to Slovenia.$^{48}$ Environmentalists has been victims of their own success by fostering green agenda in the political mainstream, and their inability to form a special identity, which is also a problem of green parties in other countries.

After the fall of communism Slovenia, as well as other transition countries, had to implement tough and far-reaching reforms that had adverse economic and social effects. ${ }^{49}$ Unintentionally, due to the closure of some factories, this was the most meaningful reduction of pollutions, however, there were insufficient funds for remedy actions altogether. Due to massive unemployment in the early 1990s environmentalists became unpopular, or were attacked in media as ones that are against development, a elitist group of individuals who do not understand the social and economic needs of small people, the nation. ${ }^{50}$

\section{Der Umweltaktivismus in Slowenien während der Zeit des Kommunismus}

\section{Zusammenfassung}

Die jugoslawische kommunistische Führung leitete nach 1945 eine ehrgeizige Strategie der Industrialisierung und Modernisierung des Landes ein, ungeachtet der Kosten. Das führte zu einer Unterordnung der sich daraus entwickelnden Fragen der Umweltzerstörung. Einige Planer waren der Meinung, dass die Umweltzerstörung ein notwendiges Übel sei, um den Versprechen von Entwicklung, Fortschritt und einem besseren Lebensstandard gerecht zu werden. Aber ab den 1970er Jahren wurden Umweltfragen durch Stadtplanung, durch verbesserte Zentralheizungssysteme, durch Festlegen von Schwellenwerten für Emissionen und durch eine obligatorische Einholung von Umweltschutzgenehmigungen bei der Gewährung von Darlehen für Wirtschaftssubjekte berücksichtigt. Bei der Umsetzung der Gesetze wurden die höchsten Normen jedoch nicht eingehalten.

Der Bund der Kommunisten Sloweniens tolerierte ab Ende der 1960er Jahre die Tätigkeit recht verbreiteter Umweltenthusiasten. Diese Gruppen bestanden aus gut gebildeten Bürgern, die zumeist leidenschaftliche Bergsteiger waren. Umweltschützer waren besonders in städtischen Gebieten aktiv, wo sie sich mit örtlichen Fragen (Stadtplanung, Abwasser, Verschmutzung von Leitungswasser und übermäßige Nutzung von Pflanzenschutzmitteln und Düngemitteln) befassten.

$49 \quad$ Lorenčič, Prelom s starim in začetek novega.

50 Interview with Alenka Bizjak, October 5, 2017. 
Lokale Umweltschutzvereine bildeten 1971 den Verein für den Umweltschutz in Slowenien (AEPS), der sich Ende der 1970er Jahre auf die Ausweitung seiner Aktivitäten konzentrierte. Diese richteten sich gegen den Bau von Wasserkraftwerken an den Flüssen Soča (Sontig) und Mur sowie, nach dem Unfall in Tschernobyl, gegen das Kernkraftwerk in Krško. In den 1970er Jahren wurde in Jugoslawien und Slowenien, zur gleichen Zeit wie im Westen, eine moderne Umweltschutzgesetzgebung verabschiedet. Neue selbstverwaltende Umweltgremien wurden gegründet, an denen sich Politiker, Rechtswissenschaftler, Juristen und Ökologen beteiligten. Dadurch wurde der Einfluss des AEPS geschmälert. Die slowenische Regierung steigerte ihre Forschungsausgaben und ersetzte zugleich in Umweltdebatten Politiker mit Technokraten, die nicht willens waren, auf die Beschwerden und Vorschläge der Umweltschützer zu hören. Die Umweltpolitiker wurden der Übertreibung bezichtigt, sie galten als Anhänger westlicher Initiativen, man warf ihnen allgemein vor, der Entwicklung im Wege zu stehen.

Nach dem GAU in Tschernobyl bekamen die Umweltschützer in den 1980er Jahren neuen Zulauf, und sie erweiterten ihre Aktivitäten. Umweltvereine zogen Menschen an, die an Veränderung interessiert waren, aber die direkte politische Opposition und die Folgen einer solchen Art der Missbilligung nicht riskieren wollten. Slowenische Umweltgruppen spielten eine wichtige Rolle im Prozess der Demokratisierung. Im Jahr 1989 gründeten sie sogar eine politische Partei, nämlich die Grünen Sloweniens. Diese Partei war Partner in der ersten slowenischen Regierung nach dem Kommunismus (1990-1992) und setzte sich erfolgreich für die Aufnahme grüner Politik in die slowenische Gesetzgebung ein.

\section{Bibliography}

\section{Archives:}

Zbirka okoljskega gradiva Alenke Bizjak [Alenka Bizjak Environmental Collection]

Archives of the Republic Slovenia, AS 2017.

Archives of the Republic Slovenia, AS 223.

\section{Literature:}

Avčin, France. Kjer tišina šepeta [Whispers of silence]. Ljubljana: Mladinska knjiga, 1964.

Berg, Marni. "Red and Gren, Twenty Years of Environmental Activism in Hungary”, Problems of Post-Communism, vol. 47 (2000), no. 2: 46-56. 
Blažič, Viktor. "Slovenske ekološke katastrofe" ["Slovenian ecological disasters”], Nova revija, New Magazine (1990), no. 93-94: 218-220.

Eichengreen, Barry. The European economy since 1945: coordinated capitalism and beyond. Princeton. N.J.: Princeton University Press, 2007.

Klemenc, Andrej; Požarnik, Hubert et al. Ekološko gibanje, politika, morala [Ecological movement, politics, and morale]. Ljubljana: Časopis za kritiko znanosti, 1992.

Kromm David E. "Perception of the air pollution hazard in Ljubljana, Yugoslavia”. In: Ivan Volgyes, ed., Enviromental Deterioration in the Soviet Union and Eastern Europe [New York, Washington, London: Praeger Publishers, 1972]: 138-140.

Lah, Avguštin. Slovenija sedemdesetih let [Slovenia in 1970's]. Ljubljana: Državna založba Slovenije, 1977.

Lah, Avguštin. "Slovenija, varstvo in urejanje okolja" ["Slovenia, protection and regulation of the environment"] In: Lah, Avguštin, ed., Slovenija 88, okolje in razvoj, zbornik [Slovenia 88, Environment and Development, Proceedings]. Ljubljana: Slovenska akademija znanosti in umetnosti, 1989: 21-24.

Lazarević, Žarko. Energetske tranzicije in oskrba z energijo, oris historičnih procesov v Sloveniji [Energy Transition and Energy Supply, Outline of Historical Processes in Slovenia] In: Lorenčič, Aleksande; Lazarević, Žarko, eds., Strategije in prakse energetske oskrbe $v$ Sloveniji [Strategies and practices of energy supply in Slovenia]. Ljubljana: Inštitut za novejšo zgodovino, 2015: 9-15.

Lorenčič Aleksander, Prelom starim in začetek novega: tranzicija slovenskega gospodarstva iz socializma $v$ kapitalizem, 1990-2004 [Break with the old regime and the new beginning: the transition of the Slovenian economy from socialism to capitalism, 1990-2004]. Ljubljana: Inštitut za novejšo zgodovino, 2012.

Mote, Victor L. "Air pollution in the USSR". In: Volgyes, Ivan, ed. Environmental Deterioration in the Soviet Union and Eastern Europe. New York, Washington, London: Praeger Publishers, 1972.

Oset, Željko. "Kemični inštitut Borisa Kidriča v letih med 1946 in 1959” ["Chemical Institute Boris Kidrič between 1946 and 1959"]. In: Stanovnik, Branko et al., eds., Maks Samec 1881-1964, življenje in delo, zbornik ob 50-letnici smrti [Maks Samec 1881-1964, life and work, a collection on the occasion of the 50th anniversary of the death]. Ljubljana: Slovensko kemijsko društvo, Slovenska akademija znanosti in umetnosti, 2015): 187-202.

Petrlin, Stane et al., eds. Zelena knjiga o ogroženosti okolja $v$ Sloveniji [The Green Book on the threat to the environment in Slovenia]. Ljubljana, Prirodoslovno društvo Slovenije, 1972.

Plut, Dušan. "Odnos do človekovega okolja v luči družbeno-ekonomskih sistemov" "Relation towards the human environment in the context of socio-economic systems"]. Geografski obzornik: časopis za geografsko vzgojo in 
izobraževanje [Geographical horizon: newspaper for geographical teaching and education] (1975), no. 3-4: 6-10.

Plut, Dušan. Slovenija - zelena dežela ali pustinja? [Slovenia - a green country or a desert?]. Ljubljana: Krtina, 1987.

Prinčič, Jože. "Gospodarska reforma" ["Ecomony reform”] In: Fischer, Jasna et al., eds. Slovenska novejšo zgodovina: od programa Zedinjena Slovenija do mednarodnega priznanja Republike Slovenije: 1848-1992. [Slovenian Contemporary History: from the Programe United Slovenia till international recognition of the Republic Slovenia: 1848-1992]. Ljubljana: Mladinska knjiga, 2005: 1045-1049.

Prinčič, Jože. "Strategije energetske stabilnosti ter pridobivanje in poraba premoga v letih 1945-1991" ["Energy Stability Strategy and Coal Production and Consumption in the period 1945-1991”]. In: Lorenčič, Aleksander, Lazarević, Žarko, eds. Strategije in prakse energetske oskrbe $v$ Sloveniji [Strategies and practices of energy supply in Slovenia]. Ljubljana: Inštitut za novejšo zgodovino, 2015.

Prinčič, Jože. Pot do slovenske narodnogospodarske suverenosti 1945-1991 [The way to Slovenian national economic sovereignty 1945-1991]. Ljubljana: Inštitut za novejšo zgodovino, 2013.

Repe, Božo; Prinčič, Jože. Pred časom, portret Staneta Kavčiča [Before time: a biography of Stane Kavčič]. Ljubljana: Modrijan, 2009.

Statistični letopis Republike Slovenije [Statistical Yearbok of the Republic of Slovenia], 1992. Ljubljana: Statistični urad Republike Slovenije, 1992.

Letopis Slovenske akademije znanosti in umetnosti, 41. knjiga, 1990 [The Yearbook of the Slovenian Academy of Sciences and Arts, Book 41, 1990]. Ljubljana: Slovenska akademija znanosti in umetnosti, 1991.

Trencsényi, Balázs; Kopeček, Michal; Lisjak Gabrijelčič, Luka; Falina, Maria; Baár, Mónika and Janowski, Maciej. A History of Modern Political Thought in East Central Europe: Volume II: Negotiating Modernity in the "Short Twentieth Century" and Beyond Part II: 1968-2018. Oxford: Oxford University Press, 2018.

Tromly, Benjamin. Making the Soviet intelligentsia: universities and intellectual life under Stalin and Krushchev. Cambridge: Cambridge University Press, 2015.

Vrdlovec Zdenko, Mako Sajko or “discovery of enigma”, September 1, 2017.

Ward, Barbara; Dubos, René. Only One Earth: The Care and Maintenance of a Small Planet. Harmondsworth: Penguin Boook Lts., 1972.

William, Cronon. Silent spring and the birth of modern environmentalism. Thomas Dunlap, DDT, Silent Spring, and the Rise of Environmentalism, classic text. Seattle: University of Washington Press, 2008. 


\section{Internet sources}

Slovenian Film Centre, Mako Sajko (https://www.film-center.si/sl/ film-v-sloveniji/filmi/2410/muzej-zahteva/), September 1, 2017

Slovenian Film Centre, Mako Sajko (https://www.film-center.si/sl/ film-v-sloveniji/filmi/2355/strupi/)

Slovenian Research Agency (Javna agencija za raziskovalno dejavnost Republike Slovenije), (https://www.arrs.si/sl/finan/letpor/), January 15, 2017

Vrdlovec Zdenko, Mako Sajko or "discovery of enigma" (Mako Sajko ali "odkritje neznanke"), Dnevnik (https://www.dnevnik.si/1042305816), September 1,2017

Youtube, Strupi - First European Ecological Movie - Mako Sajko (https:// www.youtube.com/watch?v=BtGTbjZH2rM), September 5, 2017

\section{Interview}

Interview with Alenka Bizjak (20. 1.2016). 